\title{
RESEARCH PAPER \\ In vitro bulbing for the propagation of Traubia modesta (Amaryllidaceae), a threatened plant endemic to Chile
}

\author{
Kelly Paredes ${ }^{1}$, Catherine Delaveau ${ }^{1}$, Pedro Carrasco ${ }^{1}$, Carlos Baeza $^{2}$, \\ Freddy Mora ${ }^{3}$, and Matilde E. Uribe ${ }^{1}$ \\ ${ }^{1}$ Universidad de Concepción, Facultad de Ciencias Forestales y Centro de Biotecnología, Barrio \\ Universitario s/n, Casilla 160-C. Concepción, Chile. \\ ${ }^{2}$ Universidad de Concepción, Facultad de Ciencias Naturales y Oceanográficas, Depto. Botánica. \\ Concepción, Chile. \\ ${ }^{3}$ Universidad de Talca, Instituto de Ciencias Biológicas. Talca, Chile.
}

\begin{abstract}
K. Paredes, C. Delaveau, P. Carrasco, C. Baeza, Freddy Mora, and M.E. Uribe. 2014. In vitro bulbing for the propagation of Traubia modesta (Amaryllidaceae), a threatened plant endemic to Chile. Cien. Inv. Agr. 41(2): 207-214. Critically endangered, Traubia modesta is endemic to Chile and belongs to the family Amaryllidaceae. In this research, a propagation protocol was developed for the in vitro cultivation of vegetative organs for this species. The twin scale explants were cultured in a Murashige and Skoog (MS) medium, supplemented with the growth regulators naphthaleneacetic acid (NAA) and 6-benzylaminopurine (BAP) in different concentrations. Plant preservative mixture (PPM) and polyvinyl pyrrolidone (PVP) were used as a biocide and an antioxidant, respectively. The results showed high contamination of the bulbs. There were no significant differences between the treatments with plant growth regulators. A multiplication rate of $1.3-2.2$ for bulbils was achieved, with an average of 28 bulbils per mother bulb. The natural regeneration rate is approximately $1-4$ bulbils per mother bulb once a year.
\end{abstract}

Key words: Bulbing, critically endangered species, In vitro propagation, Traubia modesta, twin scales.

\section{Introduction}

The genus Traubia is endemic to Chile and belongs to the Amaryllidaceae family. The genus contains a single species, T. modesta (Phil.) Ravenna (Ravenna, 2003). This endangered plant from central Chile is locally known as "añañuca modesta" and "añañuca blanca". This bulbous

Received January 15, 2014. Accepted July 17, 2014. Corresponding author: muribe@udec.cl plant is classified as endangered (Ravenna et al., 1998). It inhabits the coastal zones and hills from the south Coquimbo Region ( $29^{\circ} 54^{\prime} \mathrm{S}, 71^{\circ}$ $\left.15^{\prime} \mathrm{W}\right)$ to the Libertador Bernardo O'Higgins Region ( $34^{\circ} 10^{\prime} \mathrm{S}, 70^{\circ} 43^{\prime} \mathrm{W}$ ) (Baeza et al., 2009). Five populations are known to exist between Los Molles in the north and Quilpué in the south (Los Molles-Pichidangui, Altos de Petorca y Alicahue, Bosque de Zapallar, Laguna Verde and Cordillera el Melón). These locations are badly damaged by urban development (Novoa, 2007). 
T. modesta is a plant characterized by its small size. It measures $15-20 \mathrm{~cm}$ in height, with linear or slightly swollen leaves, which are dry or non present at the time of blooming. Flowers measure $15-20 \mathrm{~mm}$ in length and are pure white or white with purple veins near towards to the base, with a purple line along the back of the tepals. The fruits are capsules that contain black-shiny seeds that are flattened, rounded and with membranous edges. In its natural habitat in Chile, T. modesta blooms from January to May (Baeza et al., 2009).

Studies related to vegetative propagation of $T$. modesta are unknown; however, it is known that geophytes from Amaryllidaceae have a low natural propagation rate that ranges from approximately zero to eight bulbs per mother bulb (Santos et al., 1998; Schiappacasse et al., 2002; Angulo et al., 2003). Conventional propagation techniques for ornamental purposes have been used for the recovery of other species of endangered bulbous plants. For example, Herbertia lahue (Mol.) Goldbl. is a species from which Morales et al. (2007) obtained 1.13 bulbils per bulb, which is within the expected range found for other Chilean geophyte species such as Calydorea xiphioides Poepp. and Leucocoryne coquimbensis F. Phil (Kim et al., 1998), which produced 1.5 and 1.1 to 1.6 bulbils per mother bulb, respectively (Morales et al., 2007).

In studies performed keep carried out by Schiappacasse et al. (2002), 18 species of Chilean geophytes with ornamental potential were propagated. In these studies, a maximum of 8.6 bulbils per initial bulb were obtained by using bulb division as the method for vegetative propagation. When performing the twin-scaling separation technique with Rhodophiala bagnoldii (Herb.) Traub, the number increased to 30 bulbils per mother bulb, demonstrating the potential of these techniques.

To compare the karyotype of T. modesta with a species of the same family, Baeza et al. (2009) conducted a cytogenetic study. This study defined the chromosome morphology of $T$. modesta, which is very different from the other species in the family.
In vitro tissue culture is a very useful biotechnological technique for the production and recovery of species that are threatened or endangered. Several studies have been conducted on the propagation of bulbous species. For example, Ozel et al. (2008), for example, developed an efficient in vitro multiplication method for Ornithogalum ulophyllum Hand.-Mazz. using the twin-scaling technique. For Cyrtanthus clavatus (L'Hér.) R.A. Dyer and Cyrtanthus spiralis Burch. ex Ker Gawl., the twin scales were cultured in a liquid medium to increase the bulb production rate under aseptic conditions (Morán et al., 2003). However, Angulo et al. (2003) followed the protocols for the micropropagation of Cyrtanthus loddigesianus (Herb.) R.A. Dyer and Cyrtanthus speciosus (L.f.) Traub., and they demonstrated a high efficiency using in vitro culture protocols.

In Chile, in vitro production of bulbils from different species of the genus Rhodophiala of the Amaryllidaceae family has occurred, with bulb production ranging from 8 to 57 bulbils per mother bulb, which is higher than the natural regeneration rate (Ferrando, 2002).

The keep aim of this research was to establish a protocol for the in vitro culture of T. modesta bulbils from the twin scales. The effects of growth regulators on the multiplication of bulbils of $T$. modesta was determined to help with the proper propagation of the species. The populations of $T$. modesta are highly reduced and very vulnerable (Baeza et al., 2009), and the results of this study will contribute to the conservation of the species.

\section{Materials and methods}

\section{Plant material and culture conditions}

The bulbs of T. modesta used in this trial were collected in La Ligua, a region of Valparaíso, Chile $\left(32^{\circ} 26^{\prime} \mathrm{S}, 71^{\circ} 13^{\prime} \mathrm{W}\right)$, in sites with increasing urbanization. Surface sterilization of the collected bulbs was performed before beginning in vitro cultures. Roots, the upper-third of the stem, and 
dry outer scales were removed. The samples were washed with antibacterial soap and a brush under tap water for $10 \mathrm{~min}$. Subsequently, the samples were placed in a solution with $1.5 \mathrm{~g} \mathrm{~L}^{-1}$ of Polyben $50 \mathrm{WP}\left(\mathrm{Anasac}^{\mathrm{TM}}\right.$ ) and $200 \mathrm{mg} \mathrm{L}^{-1}$ of streptomycin sulfate $\left(\right.$ Calbiochem $\left.{ }^{\mathrm{TM}}\right)$ for $24 \mathrm{~h}$. After this period, under a laminar-flow chamber with constant agitation, the bulbs were rinsed in sterile distilled water for $3 \mathrm{~min}$ to begin the process of surface asepsis. The bulbs were immersed in a $70 \%$ ethanol solution for $2 \mathrm{~min}$, followed by 3 rinses with sterile distilled water of 3, 4 and $5 \mathrm{~min}$. They were further disinfected in a $40 \%(\mathrm{v} / \mathrm{v})$ commercial bleach solution with $2.5 \%$ active bleach with two drops of common dish soap (Quix ${ }^{\circledR}$ ) for 15 min, which was followed with a triple rinse with sterile distilled water. Bulbs were kept in sterile distilled water during the introduction of the scales to the growth medium to prevent the desiccation of the material.

The growth medium for this experiment was the MS medium (Murashige and Skoog, 1962), supplemented with $30 \mathrm{~g} \mathrm{~L}^{-1}$ of sucrose. To prevent tissue oxidation, $0.5 \mathrm{~g} \mathrm{~L}^{-1}$ of polyvinyl pyrrolidone (PVP, Calbiochem $^{\mathrm{TM}}$ ) was used, and as a biocide, $1 \mathrm{~mL}$ of plant preservative mixture $\left(\mathrm{PPM}^{\mathrm{TM}}\right)$ was added. Once the growth solution was prepared and before sterilization, the $\mathrm{pH}$ was adjusted to 5.8. The medium was gelated with $8 \mathrm{~g} \mathrm{~L}^{-1}$ of plant agar (Duchefa). Flasks or test tubes with the growth medium were autoclaved for $20 \mathrm{~min}$ at $1 \mathrm{~atm}$ of pressure at $121^{\circ} \mathrm{C}$.

Explants were placed in either test tubes with $10 \mathrm{~mL}$ or in glass flasks with $30 \mathrm{~mL}$ of growth medium. Explants were incubated in a growth chamber at $25 \pm 1{ }^{\circ} \mathrm{C}$ and $55 \%$ relative humidity with a $16 \mathrm{~h}$ photoperiod with the cold light at an intensity of $40 \mu \mathrm{mol} \mathrm{m} \mathrm{m}^{-2} \mathrm{sec}^{-1}$.

\section{Establishment and induction stage}

Once the bulbs were aseptic, they were sectioned into eight longitudinal slices that were separated in the twin scale explants, with a portion of the basal disk. These scales were vertically inserted into the tubes with the MS growth medium. To identify the optimal concentration, different concentrations of different growth regulators were added to the medium. These treatments were as follows: (A) without growth regulators, (B) supplemented with $1.0 \mathrm{mg} \mathrm{L}^{-1}$ of 6-benzylaminopurine (BAP) and $0.5 \mathrm{mg} \mathrm{L}^{-1}$ of naphthaleneacetic acid (NAA), (C) $0.5 \mathrm{mg} \mathrm{L}^{-1}$ of BAP and $1.0 \mathrm{mg} \mathrm{L}^{-1}$ of NAA, and (D) $1.0 \mathrm{mg} \mathrm{L}^{-1}$ of BAP and $1.0 \mathrm{mg} \mathrm{L}^{-1}$ of NAA.

The experimental unit was a test tube with one explant; treatment A had 56 explants, and treatments B, C and D each had 64 explants. The experiment was a completely randomized design. In the first three subcultures of this phase, the number of contaminated, necrotic and viable explants was counted. In the final count, those explants that were not contaminated were selected for the multiplication phase.

In the statistical analyses, a Generalized Linear Model (deviation analysis) was used, with a binomial distribution of the response variables (viable, contaminated and necrotic explants) and a logarithmic link function. Analyses were performed with the SAS ${ }^{\circledR}$ GENMOD software procedure (SAS Institute, Cary, North Carolina, USA).

\section{Multiplication phase}

Uncontaminated viable explants obtained from the establishment and induction phase were cultured in fresh media in $5.5 \mathrm{~cm}$ diameter by $6.5 \mathrm{~cm}$ high glass flasks with $30 \mathrm{~mL}$ MS growth medium for the following treatments: (A) without growth regulators, (B) supplemented with $3.0 \mathrm{mg} \mathrm{L}^{-1}$ of BAP and $0.5 \mathrm{mg} \mathrm{L}^{-1}$ of NAA, (C) $2.0 \mathrm{mg} \mathrm{L}^{-1}$ of BAP and $1.0 \mathrm{mg} \mathrm{L}^{-1}$ of NAA, and (D) $2.0 \mathrm{mg} \mathrm{L}^{-1}$ of BAP and $2.0 \mathrm{mg} \mathrm{L}^{-1}$ of NAA.

The number of new bulbils per treatment was assessed. The data were subjected to statistical analyses, accounting for a Poisson distribution for the number of new bulbils variable. The General- 
ized Linear Model under the GENMOD procedure $\left(\mathrm{SAS}^{\mathrm{TM}}\right)$ was used with a logarithmic link function (Myers et al., 2002; Mora et al., 2010).

\section{Results and discussion}

\section{Establishment and induction stage}

The twin scales of $T$. modesta were highly contaminated because they came directly from their natural habitat, with contamination reaching $50 \%$ to $80 \%$ of the total number of explants per treatment. This contamination is associated with the activity of fungi and bacteria in the internal tissues of the plant material (Alvarado, 1998). According to Pierik (1990), although the plant material is surface-sterilized before culturing, complete sterilization is not possible. The analyses of deviations in the subcultures showed significant differences among the treatments for percentages of viability, contamination and necrosis of the explants (Table 1).

Table 1. Deviation analyses (Chi-square test) of viable, contaminated and necrotic explants in the in vitro bulbing experiment with Traubia modesta.

\begin{tabular}{lcccc}
\hline & & \multicolumn{3}{c}{ Chi-square } \\
\cline { 3 - 5 } Source & DF & Viable & Contaminated & Necrotic \\
\hline Intercept & & & & \\
Treatment & 3 & $25.45^{*}$ & $21.34^{*}$ & $5.91 \mathrm{~ns}$ \\
Time & 3 & $101.96^{*}$ & $45.63^{*}$ & $101.64^{*}$ \\
\hline
\end{tabular}

$* \mathrm{P} \leq 0.05, \mathrm{~ns}=$ not significant, and $\mathrm{DF}=$ degrees of freedom.

The high percentage of contamination observed during the establishment phase in this study has been previously recognized, and such contamination represents the main challenge for micropropagation (Smith et al., 1999). For example, the bulbs of Narcissus sp. (Amaryllidaceae) contain a mucilage in which pathogenic organisms live that are difficult to eliminate with surface sterilization (Sochacki and Orlikowska, 2005). Chang et al. (2003) found that the marshy habitat that Zantedeschia sp. (Araceae) inhabited was favorable for the development of bacteria and decomposer fungi in the tubers, which caused great losses for the commercial propagation of this species. Additionally, they maintained that the endogenous contamination was the greatest problem with the propagation of the tubers. Thermotherapy and fungicides in combination with immersions in $\mathrm{NaOCl}$ solutions can lower survival rates and eliminate contamination (Bruyn et al., 1992).

According to Slabbert et al. (1993), to avoid the contamination problem with Crinum macowanii Baker, a selection of bulbs was performed. The bulbs were collected and placed in the greenhouse. An induction phase was started, and the material that presented some degree of contamination could be discarded (20\% to $40 \%$ of the scales from $C$. macowanii). Moreover, Ault (1995) found 90\% of the contaminated plant material in the establishment phase for Eucomis autumnalis. For Sprekelia formosissima, Cázarez et al. (2010) found better results following previous trials with disinfection methodologies, with $89.1 \%$ of the explants axenic.

The results from the present study agree with those obtained by Ferrando (2002) who found that the contamination percentages were so high that it was concluded that any asepsis method used for the three species of Rhodophiala would be favorable for the multiplication of the species. In the current study, the contamination was only by fungi because the bacterial contamination could be efficiently controlled with streptomycin and PPM as biocides. The decision to include an antibiotic, such as streptomycin, was made following Ferrando (2002), who recommended using these substances because of the endogenous bulb contamination. Streptomycin sulfate is widely used as antibiotic for in vitro cultures. However, PPM has proved to be efficient in controlling exogenous fungal and bacterial contamination in in vitro cultures (Digonzelli et al., 2005). With Amaryllis species, low contamination rates of the explants were achieved with different concentrations of PPM (Smith et al., 1999). With R. bifida, Rodrigo et al. (2006) found that the seeds treated with PPM were aseptic and had low levels of contamination, with no effect of PPM on later development or morphology. 
The percentage of viable explants varied among the different hormone treatments and with the time grown in these media. For viability, a maximum of $42.2 \%$ of the explants were viable in treatment D (Table 2).

Table 2. Analyses of the significant differences among treatments for viable and contaminated explants of Traubia modesta.

\begin{tabular}{lcccccc}
\hline & \multicolumn{2}{c}{ Viable } & & \multicolumn{2}{c}{ Contaminated } \\
\cline { 2 - 3 } \cline { 6 - 7 } Contrast & $\mathrm{Chi}^{2}$ & $\mathrm{P}>\mathrm{Chi}^{2}$ & & $\mathrm{Chi}^{2}$ & $\mathrm{P}>\mathrm{Chi}^{2}$ \\
\hline A versus B & 11.23 & $0.0008^{*}$ & & 10.91 & $0.0010^{*}$ \\
A versus C & 0.79 & 0.3743 & & 0.26 & 0.6081 \\
A versus D & 21.35 & $<.0001^{*}$ & & 13.98 & $0.0002^{*}$ \\
B versus C & 6.54 & $0.0105^{*}$ & & 8.38 & $0.0038^{*}$ \\
B versus D & 1.77 & 0.1836 & & 0.21 & 0.6490 \\
C versus D & 15.05 & $0.0001^{*}$ & & 11.20 & $0.0008^{*}$ \\
\hline
\end{tabular}

$* \mathrm{P} \leq 0.05$.

Another disadvantage of working with bulbous species is the oxidation and the necrosis of the tissues that occurs. Oxidation and darkening of the in vitro cultured explants is produced by the reaction of free radicals, as well as the oxidation of phenolic compounds (Ferrando, 2002; Azofeifa, 2009). In this study, a rapid oxidation of the tissues in the zone where the sections were performed was observed. The maximum percentage of material lost by this oxidation reached $20.3 \%$. In the case of Rhodophiala, Ferrando (2002) used antioxidant baths of citric and ascorbic acids, as well as drops of sodium diethylthiocarbamate, but the results were not as expected and almost all the material was lost. With Hippeastrum spp., necrosis and browning was observed in the third and fourth subcultures (Seabrock and Cumming, 1977).

In summary, with the contamination and subsequent oxidation leading to necrosis, the maximum survival of the treated explants varied between 5 and $15 \%$ in the later phases of the culture.

\section{Multiplication phase}

The scales used during the establishment and induction process had low rates of development of new shoots, so those with the most regeneration were selected for the multiplication phase. These were transferred to growth media with different concentrations of growth regulators; greater than those used in the establishment and induction stage. These scales produced new bulbs (Table 3 ) with new shoot formations present in all treatments (Figure 1).

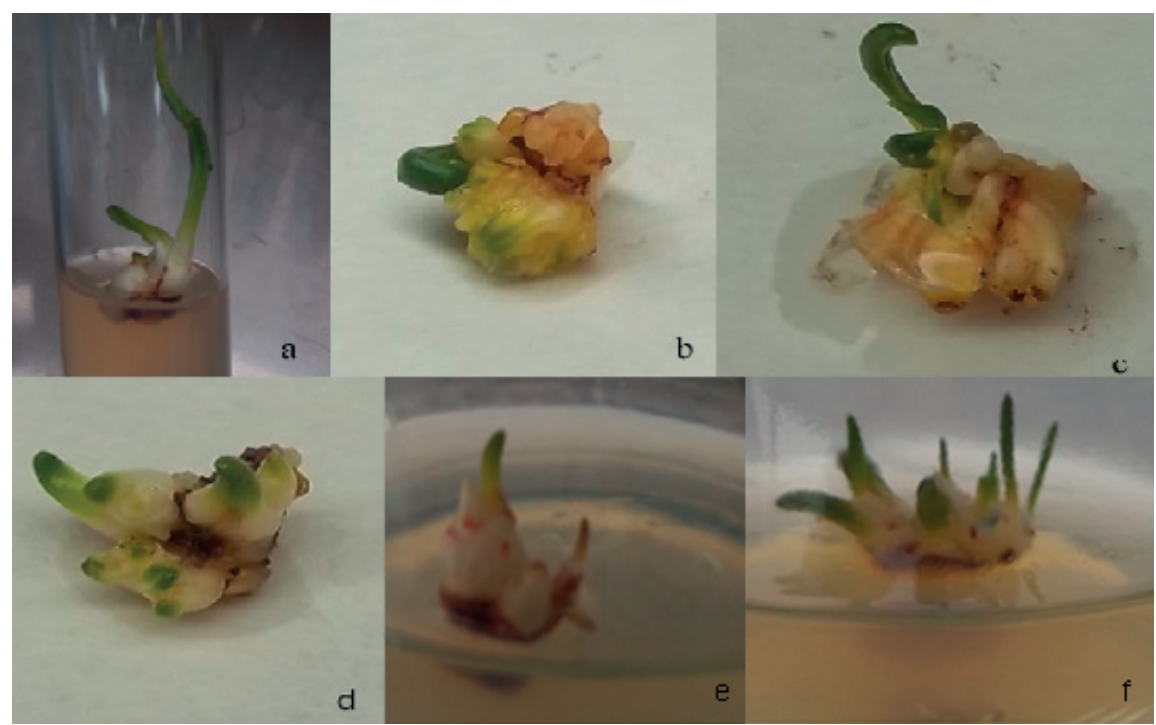

Figure 1. Bulb multiplication of Traubia modesta: (a) material obtained from the growth and induction phases, (b, c and d) new formations in the multiplication phase, and (e and f) new bulbils of Traubia modesta produced in vitro with growth regulator in treatment D $\left(2.0 \mathrm{mg} \mathrm{L}^{-1}\right.$ of BAP and $2.0 \mathrm{mg} \mathrm{L}^{-1}$ of NAA). 
Table 3. Number of new bulbs of Traubia modesta per treatment during three subcultures.

\begin{tabular}{lcccc}
\hline SCV $(\mathrm{d})$ & TREAT & N & NNB & IC \\
\hline 30 & A & 14 & 1.29 & \pm 0.53 \\
& B & 16 & 1.31 & \pm 0.54 \\
& C & 21 & 1.29 & \pm 0.39 \\
80 & D & 15 & 1.73 & \pm 0.44 \\
& A & 14 & 1.21 & \pm 0.41 \\
& B & 16 & 1.94 & \pm 1.18 \\
& C & 21 & 1.52 & \pm 0.55 \\
120 & D & 15 & 2.47 & \pm 0.98 \\
& A & 14 & 1.64 & \pm 1.58 \\
& B & 16 & 2.50 & \pm 2.13 \\
& C & 21 & 1.33 & \pm 0.44 \\
& D & 15 & 2.20 & \pm 0.92 \\
\hline
\end{tabular}

$\mathrm{N}=$ Number of individuals, $\mathrm{NNB}=$ Number of new bulbs, TREAT $=$ treatment, $\mathrm{SCV}=$ subculture, $\mathrm{d}=$ days, and $\mathrm{IC}=$ confidence interval of $95 \%$. A. without growth regulators, B. $3.0 \mathrm{mg} \mathrm{L}^{-1}$ of BAP and $0.5 \mathrm{mg} \mathrm{L}^{-1}$ of NAA, C. $2.0 \mathrm{mg} \mathrm{L}^{-1}$ of BAP and $1.0 \mathrm{mg}$ $\mathrm{L}^{-1}$ of NAA, and D. $2.0 \mathrm{mg} \mathrm{L}^{-1}$ of BAP and $2.0 \mathrm{mg} \mathrm{L}^{-1}$ of NAA.

According to the deviation analyses, there were no significant differences among the treatments (Chi-square $=4.01$ and the associated probability of 0.26; Poisson distribution in a Generalized Linear Model). Therefore, the treatments can be used interchangeably. However, the treatment without growth regulators would be ideal because of the decreased cultivation costs and the minimal treatment of the vegetal material (Uribe et al., 2011).

The results from the current study agree with those obtained for other species of the Amaryllidaceae family. For example, in the case of $R$. montana, Jara et al. (2007) found a shoot regeneration percentage of cultured twin scales of less than $20 \%$. The average number of bulbs obtained in all treatments was 28 per mother bulb, which is more than seven-fold the natural regeneration rate.
For Hippeastrum spp. hybrids (Seabrook and Cumming, 1977), there was greater production of shoots in a growth medium without growth regulators. The same result was found for Crinum macowanii (Slabbert et al., 1993) and for the beginning cultivation phase of Eucomis comosa and Eucomis zambesiaca (Ault, 1995).

Regarding the micropropagation of Amaryllidaceae, several studies emphasized the necessity of determining the optimal concentration of growth regulators required by each species in each phase of the in vitro culture. There are species that need higher concentrations of cytokinins (Cázarez et al., 2010; Uranbey, 2010), whereas others require auxins (Piña-Escutia et al., 2010) in equivalent concentrations (Azadi and KhoshKhui, 2007). Furthermore, there are species that require no addition of growth regulators. In the present study, however, the low availability of plant material did not allow for studies on the interactions between hormones. However, it is recommended that such studies are conducted with T. modesta and that these studies should include other types of growth regulators at varied concentrations with different types of growth media, among other factors.

In summary, for T. modesta, it is possible to obtain large-scale production of bulbs. A bulbil multiplication rate of 1.3 to 2.2 and an average of 28 bulbs were obtained per mother bulb in all treatments, which is more than seven-fold the natural regeneration rate. According to the results, it is recommended that treatments prior to in vitro cultures be developed to obtain axenic cultures more successfully, in addition to counting on a larger number of bulbs 


\section{Resumen}

K. Paredes, C. Delaveau, P. Carrasco, C. Baeza, Freddy Mora y M.E. Uribe. 2014. Formación de bulbos in vitro de Traubia modesta (Amaryllidaceae), una planta amenazada endémica de Chile. Cien. Inv. Agr. 41(2):207-214. Traubia modesta pertenece a la familia Amaryllidaceae y es endémica de Chile, que se encuentra en la categoría de "en peligro" de extinción. En esta investigación se desarrolló un protocolo de propagación de la especie a través del cultivo in vitro de órganos vegetativos. Se utilizó la técnica de escamas gemelas cultivadas en medio MS suplementado con ANA y BAP en distintas concentraciones, se adicionó PPM como biocida y PVP como compuesto antioxidante. Los resultados obtenidos muestran una alta contaminación en los bulbos. No hubo diferencias significativas entre los tratamientos con reguladores del crecimiento vegetal. Se logró una tasa de multiplicación de microbulbillos de 1,3 a 2,2, donde el promedio de bulbos obtenidos en todos los tratamientos por bulbo madre fue de 28. La regeneración natural es alrededor de 1 a 4 unidades por bulbo madre una vez al año.

Palabras clave: Bulbificación, escamas gemelas, especie en peligro de extinción, propagación in vitro, Traubia modesta.

\section{References}

Alvarado, Y. 1998. Contaminación microbiana en el cultivo in vitro de plantas. In Pérez JN (ed.). Propagación y mejora genética de plantas por biotecnología. Instituto de Biotecnología de las Plantas, Cuba p. 81-104.

Angulo, M., R. Colque, F. Viladomat, J. Bastida, and C. Codina. 2003. In vitro production of bulblets of Cyrtanthus loddigesianus and Cyrtanthus speciosus. Journal of Horticultural Science and Biotechnology 78:441-446.

Ault, J. 1995. In vitro propagation of Eucomis autumnalis, E. comosa and E. zambesiaca by twinscaling. HortScience 30:1441-1442.

Azadi, P., and M. Khosh-Khui. 2007. Micropropagation of Lilium ledebourii (Baker) Boiss as affected by plant growth regulator, sucrose concentration, harvesting season and cold treatments. Electronic Journal of Biotechnology 10:582-591.

Azofeifa, A. 2009. Problemas de oxidación y oscurecimiento de explantes cultivados in vitro. Agronomía Mesoamericana 20:153-175.

Baeza, C., P. Novoa, E. Ruíz, and M. Negritto. 2009. El cariotipo fundamental en Traubia modesta (Phil.) Ravenna (Amaryllidaceae). Gayana Botánica 66:297-300.
Bruyn, M., D. Ferreira, M. Slabbert, and J. Pretorius. 1992. In vitro propagation of Amaryllis belladonna. Plant Cell Tissue and Organ Culture 31: 179-184.

Cázarez, M., M. Andrade, A. Villegas, I. Tejacal, O. Villegas, and V. López. 2010. In vitro propagation of Sprekelia formosissima Herbert. a wild plant with ornamental potential. Revista Fitotecnia Mexicana 33:197-203.

Chang, H., E. Chakrabarty, E. Hahn, and K. Paek. 2003. Micropropagation of Calla Lily (Zantedeschia albomaculata) via in vitro shoot tip proliferation. In Vitro Cellular and Development Biology - Plant 36:129-134.

Digonzelli, P., L. Díaz, and S. Carrizo. 2005. Uso de PPM (Plant Preservative Mixture) para controlar contaminantes bacterianos en la multiplicación in vitro de caña de azúcar. Revista de la Facultad de Agronomía 22:22-32.

Ferrando, M. 2002. Multiplicación in vitro de las especies Rhodophiala montana (Phil.) Traub., Rhodophiala rhodolirion (Baker) Traub. y Rhodophiala splendens (Rengifo) Traub. Tesis para optar al grado de Licenciado en Agronomía. Universidad Austral de Chile. Facultad de Ciencias Agrarias. Escuela de Agronomía. Valdivia, Chile. 82 pp. 
Jara, G., P. Seemann, and M. Muñoz. 2007. Cultivo in vitro y aclimatización de plántulas de Rhodophiala montana. Agro Sur 35:50-52.

Kim, H.H., K. Ohkawa, and E. Nitta. 1998. Effects of bulb weight on the growth and flowering of Leucocoryne coquimbensis F. Phil. Acta Horticulturae 454:341-346.

Mora, F., C.A. Scapim, A. Baharum, and A.T. Amaral Júnior. 2010. Generalized composite interval mapping offers improved efficiency in the analysis of loci influencing non-normal continuous traits. Ciencia e Investigación Agraria 37:83-89.

Morales, P., P. Peñailillo, P. Yañez, and F. Schiappacase. 2007. Efecto del peso del bulbo sobre el crecimiento vegetativo y reproductivo de Herbetia lahue (Molina) Goldbl. subsp. Lahue (Iridaceae). Agro Sur 35:28-30.

Morán, G., R. Colque, F. Viladomat, J. Bastida, and C. Codina. 2003. Mass propagation of Cyrtanthus clavatus and Cyrtanthus spiralis using liquid medium culture. Scientia Horticulturae 98:49-60.

Murashige, T., and F. Skoog. 1962. A revised medium for rapid growth and bioassays with tobacco cultures. Physiologia Plantarum 15:473-497.

Myers, R.H., D.C. Montgomery, and G.G. Vining. 2002. Generalized linear models, with applications in engineering and the sciences. John Wiley and Sons Press, New York. USA. 342 pp.

Novoa, P. 2007. Daño en el Sitio Prioritario Los Molles-Pichidangui. Available online at: http:// www.chilebosque.cl/foro/viewtopic.php?t $=438$ (Website accessed: April 18, 2011).

Ozel, C.A., K. Khawar, S. Karaman, M. Ates, and O. Arslan. 2008. Efficient in vitro multiplication in Ornithogalum ulophyllum Hand.-Mazz. from twin scale explant. Scientia Horticulturae 116:109-112.

Pierik, R. 1990. Cultivo in vitro de plantas superiores. Ediciones Mundi-Prensa. Madrid, España. $301 \mathrm{pp}$.

Piña-Escutia, J., L. Vásquez-García, and A. ArzateFernández. 2010. In vitro regeneration and ge- netic fidelity of Tigridia pavonia (L.f.) DC. Electronic Journal of Biotechnology 13:1-7.

Ravenna, P. 2003. Elucidation and systematics of the Chilean genera of Amaryllidaceae. Botánica Australis 2:1-21.

Rodrigo, J., F. Rosselló, P. Marinangeli, and N. Curvetto. 2006. Germinación in vitro de Rhodophiala bifida. 3er. Congreso Argentino de Floricultura, 8a Jornadas Nacionales de Floricultura. La Plata, Argentina. 7-10 noviembre.

Santos, J., I. Santos, and R. Salema. 1998. In vitro production of bulbs of Narcissus bulbocodium flowering in the first season of growth. Scientia Horticulturae 76:205-217.

Schiappacasse, F., P. Peñailillo, and P. Yañez. 2003. Propagación de bulbosas chilenas ornamentales. Editorial Universidad de Talca. Talca. Chile. 65 pp. Seabrock, J., and B. Cumming. 1977. The in vitro propagation of Amaryllis (Hippeastrum spp. hybrids). In vitro 13:831-836.

Slabbert, M., M. Bruyn, D. Ferreira, and J. Pretorius. 1993. Regeneration of bulblets from twin scales of Crinum macowanii in vitro. Plant Cell Tissue and Organ Culture 33:1331-1341.

Smith, R., J. Burrows, and K. Kurten. 1999. Challenges associated with micropropagation of Zephyranthes and Hippeastrum sp. (Amaryllidaceae). Workshop on micropropagation. In Vitro Cellular and Development Biology - Plant 35:281-282.

Sochacki, D., and T. Orlikowska. 2005. The obtaining of narcissus plants free from potyviruses via adventitious shoot regeneration in vitro from infected bulbs. Scientia Horticulturae 103:219225.

Uranbey, S. 2010. In vitro bulblet regeneration from immature embryos of Muscari azureum. African Journal of Biotechnology 32:5121-5125.

Uribe, M.E., R. Durán, G. Bravo, F. Mora, P. Cartes, and C. Delaveau. 2011. Propagación vegetativa de Berberidopsis corallina Hook. f., una especie en peligro de extinción, endémica de Chile. Gayana Botánica 68:135-140. 